relatively slow rate of progress may be intorpreted as showing that increasing mechanization is making incentive schemes redundant. It may also mean that they have already been applied to most of the tasks for which they are appropriate. Whether incentive schomes can be made effective will have to be assessed within a much wider framework of life, both inside and outside the factory. The discussion indicates where further inquiries may increase understanding of the problems of co-operation between workers and management. Financial incentives may bo an important aspect of these investigations.

Canadian Department of Mines and Technical Surveys: Marine Sciences Branch

THe Canadian Federal Government is establishing a Marine Seiences Branch in the Department of Mines and Technical Surveys to combine hydrographic surveys and research in oceanography, marine geology and the geophysical sciences of the seas. The new Marine Sciences Branch will commence activities as from April 1. Its functions will be to carry out hydrographic and other oceanic surveys and to conduct occanographic research in the nearby oceans, in Canada's coastal and inland waters, and on the underlying sea-beds for the threefold purpose of assisting navigation, with particular reference to Arctic waters, of ascortaining the resource potential of the country's continental shelf, and of undertaking the extensive programme of oceanographic research required for military and civilian purposes. The resultant information will also greatly assist the commercial fisheries. Mr. S. G. Gamble, director of the Department's Surveys and Mapping Branch, will act as director of the now branch pending the appointment of a director. The new Marine Sciences Branch will be serviced by a fleet of multi-purpose ships which aro designed to bo used for either survey or research purposes. The ships are being provided under a long-range shipbuilding programme. For the east coast, three ships are in design or under construction, and one ship, the Maxwell, was launched during the past field season. The largest of the group, the Hudson, is expected to be commissioned in 1963. On the west coast, the Department recently assumed the responsibility for the operation of the M.V. Ehkoli, a reconverted naval ship. It will use the Ehkoli for oceanographic research and to assist the Institute of Ocoanography of the University of British Columbia in its oceanographic training programme. A new survey and research ship for the west coast is in the design stage.

\section{Geological Research in the United States}

TWELVE months ago the United States Geological Survey published, as an experiment, a report giving brief synopses of the researches exocuted by its staff during the fiscal year ending June 1960. The experiment was widely welcomed, for the new publication amply fulfillod a commendable objective of releasing the salient results of investigations far moro quickly than had been possible in detailed reports and monographs; and in consequence of this good reception a similar report has been issued for 1961, now oxtonded to cover hydrological as woll as geological activities. This report appears as four quarto volumes totalling xxxvi + 1,344 pp. ((Y)eological Survey Iesearch 1961: U.S. Geological Survey Prof. Paper 424. Part A, Synopsis of Results, pp. 194; Parts B, C, D, Short Papers in the Geologic and Hydrologic Sciences, pp. $344+398+408$. U.S. Gov. Printing Office, Washington, D.C., 1961). In Part $A$ there is given a review of the principal recent discoveries of scientific and economic interest made by the Survey in the wide range of its work, together with a list of the investigations in progress and the titles of more than a thousand publications issued during this year. Parts $\mathrm{B}, \mathrm{C}$ and $\mathrm{D}$ comprise 435 short papers distributed over the specialist subjects geophysics (30 contributions), mineralogy, geochemistry and petrology (66), palæontology, geomorphology and plant ecology (27), exploration and mapping techniques (14), engineering geology and public health (14), analytical and petrographic methods (28), hydrology (47), metalliferous deposits (14) and fuels (2); as well as regional studies on the geology and hydrology of the United States (159), Alaska and Hawaii (13), Pucrto Rico, Pacific Islands and Antarctica (8), and foreign countries (16). One paper deals with the stratigraphical succession of the rocks of the Moon. The publication of this extensive and well-produced review within five months of the close of the year to which it refers is a remarkable achievement in scientific reporting, and both the Geological Survoy and the Government Printing Office deserve congratulations.

\section{British Library of Political and Economic Science}

THE annual report for 1960-61 of the British Library of Political and Economic Science notes a 9 per cent increase in the average cost of treatises bought and a similar inereaso in the average serials subscription ( $\mathrm{Pp}$. 15. London: British Library of Political and Economic Science, University of London, 1961). These were covered by an increase of $£ 1,000$ in the vote for book purchases, expenditure on treatises and on periodicals and other serials being $\mathfrak{1} 8,713$ and $£ 7,239$, respectively (out of total purchases of $£ 15,523$ ). Acquisitions of troatises totalled 6,641, of pamphlets 1,193, of non-serial Government publications 3,255 , and of current serials 8,429 , and the total of individual items is estimated at $1,155,000$ items, of which 396,918 are bound volumes in the Library itself, 8,826 in study rooms, 11,958 in the lending library, and 4,903 in the Shaw library.

\section{Graduate Careers}

Graduate Careers, a bi-monthly magazine devoted to all aspects of careers, has recently beon launched. More than 15,000 copies are being distributed through appointments boards, unions and colleges, free of charge to all undergraduates in their final year. The journal is published by New Homos Press, Ltd., and edited by P. W. Kingsland, who, together with John Ashby, of British Overseas Airways Corporation, pioneered tho idea (1, No. 1; Novembor, 1961. Pp. 36. London: New Homes Press, Ltd., 14 Bury Street, E.C.3, 1961). The editorial content of the magazino is devoted to features about individual industries, and about specialist careers within and without industry. The magazine also carries a column of news items and some bonk roviows. It is financed by display advertisements.

The first issue contains articles on "Careers in the City", "Flying-For the Few ?", a graduate careers survoy of the automation industry showing prospects for the industry itself and for potential automation engineers, and an article on apprenticeships in the clectrical engineering industry. The second issue will cover steel, public relations, the chartered secretary, work study and commercial air transport. 